\title{
Progression i högre utbildning
}

\author{
Anna Ida Säfström* \\ Akademin för Lärande, Humaniora och Sambälle, Högskolan i Halmstad
}

\begin{abstract}
SAMMANFATTNING
Syftet med denna studie är att undersöka innebörden och användningen av ordet progression inom högre utbildning. För att ta reda på i vilka betydelser ordet progression används, och hur användningen av ordet har förändrats över tid, genomförs här en systematisk begreppsanalys av vetenskapliga texter, statliga styrdokument och texter hämtade från svenska lärosätens hemsidor. Som utgångspunkt för analysen särskiljs progression i dess klassiska betydelse och progression som en kvalitet i utbildning, undervisning och läromedel. Resultatet av analysen visar att ordet progression används i allt högre utsträckning, men ofta med oklar betydelse. Det framkom också att det har skett en förskjutning mot användning av ordet progression som kvalitet hos utbildning. En definition av utbildningsprogression föreslås, och konsekvenser för högre utbildning diskuteras.
\end{abstract}

Nyckelord: progression, högre utbildning, systematisk begreppsanalys

\section{BAKGRUND}

Den svenska högskolesektorn har under det senaste decenniet genomgått ett antal förändringar och kvalitetsutvärderingar (Prop. 2004/05:I62; SFS 2006:I73; SFS 2006:1053; Prop. 2009/I0:89; Prop. 2009/IO:I39), delvis som en följd av Bolognaprocessen. Dessa former av statlig styrning har naturligtvis påverkat högskolesektorn direkt, inte minst ekonomiskt. Under perioden 20II2014 utvärderade Högskoleverkets (HSV) och Universitetskanslersämbetets (UKÄ) I86o utbildningar, och de självvärderingar lärosätena producerat som en del av underlaget uppskattas, av Adamson (2013), ha kostat mellan I5O och 225 miljoner kr. Totalt fanns 504 utbildningar vara av bristande kvalitet, vilket lett till antingen nedläggning eller omfattande utveckling av kurser och program, vilket också innebär minskade resurser och ökade omkostnader för lärosätena. Buhre (20I4) visar på att utvärderingarnas upplägg och fokus speglar en viss kunskapssyn, där ett visst kunskapsuttryck - akademisk, skriven text - premieras, medan muntliga och praktiska uttryck inte tillmäts samma värde. Hon menar också att dessa utvärderingar riskerar att bli normerande, och därmed påverka lärosätenas utformning av utbildning och undervisning i framtiden.

Den statliga granskningen av utbildningarna kan dock även ha påverkat lärosätena och deras anställda på mer subtila sätt. Clegg (2009) menar att vårt sätt att tänka på undervisning formas genom införandet av ett visst språkbruk om utbildning, undervisning och lärande. Det är en grundläggande idé inom forskning att det perspektiv, eller den förförståelse, vi har formar våra tankar i det att de påverkar vilka frågor vi ställer, hur vi tar oss an dessa frågor, och hur vi formulerar våra svar. Att analysera och klargöra begrepp är därmed en viktig del i all vetenskaplig forskning (Nuopponen, 2OII, s 4).

\footnotetext{
* Författarkontakt: Anna Ida Säfström, anna_ida.safstrom@hh.se

Artiklar och reflektioner är kollegialt granskade. Övriga bidragstyper granskas av redaktionen. Se www.hogreutbildning.se ISSN 2000-7558

(C)2017 Anna Ida Säfström. This is an Open Access article distributed under the terms of the Creative Commons Attribution-NonCommercial 4.0 International License (https://creativecommons.org/licenses/by-nc/4.0/), allowing third parties to share their work (copy, distribute, transmit) and to adapt it, under the condition that the authors are given credit, that the work is not used for commercial purposes, and that in the event of reuse or distribution, the terms of this license are made clear.

Citation: Anna Ida Säfström (2017) «Progression i högre utbildning», Högre utbildning 7, 56-75. http://dx.doi.org/10.23865/hu.v7.955
} 
Om detta tas på allvar i forskning borde det också tas på allvar i undervisning och utformande av utbildning. Vilka begrepp högskolor och universitet väljer att använda då de talar om utbildning, hur de använder dessa begrepp, och vad det ger för perspektiv på utbildning är alltså något som kräver analys och reflektion. Om lärosätena okritiskt anammar de begrepp och formuleringar som utvärderingar och styrdokument använder, kommer verksamheten också att påverkas av den kunskapssyn de speglar - en kunskapssyn som högskolan och den enskilde läraren kanske inte delar, och som kanske inte har stöd i forskning kring lärande och högre utbildning.

I denna studie analyseras ordet progression och dess användning i olika typer av text. Progression är ett ord som vinner mark i högskolesektorns språkbruk, ofta i relation till nivåerna i den nya utbildningsstruktur som infördes 2007 som ett led i Bolognaprocessen (UKÄ, 2017). Som ett exempel talar Elmgren och Henriksson (2013) i boken Universitetspedagogik om studenternas "progression genom utbildningen" (Elmgren \& Henriksson, 20I3, s I4O, 218), men också om att lärandemålen bör uppvisa en progression (Elmgren \& Henriksson, 20I3, s 209) och att den mån i vilken studenternas tidigare kunskaper tas tillvara kan ses som ett mått på hur väl utbildningens progression fungerar (Elmgren \& Henriksson, 2013, s I5O). Att språkbruket spritt sig till lärosätena visar sig i att många av dem har genomfört arbete med olika progressionsdokument, till exempel med avseende på ämneskunskaper, praktiska färdigheter och, kanske främst, vetenskaplighet. Ordet progression är inte nytt inom högskolesektorn, utan har tidigare använts som synonym till utveckling, med avseende på kunskap hos elever och studenter (Prop. 1992/93:220; Prop. 1992/93:250).

Utbildningens progression visar sig också vara en viktig förutsättning för att få examenstillstånd, vilket visar sig i att 37 av UKÄs 45 beslut och yttranden om examenstillstånd lyfter fram förekomst av progression i utbildning eller kurser (sökning 2016-05-3I på www.uka.se "Ansökan om tillstånd att utfärda"). I sin rapport om utvärderingssystemet 20II-20I4 framhåller UKÄ också "tydligare progression mellan kurser" som en följd av utvärderingen (UKÄ 20I4:II, s 30), och att erfarna lärare vet att "Kurser byggs $i$ en viss progression mot ett examensarbete som utgör en funktion av tidigare kurser" (UKÄ 2OI4:II, s 23). Formuleringarna skärps i rapporten Högre utbildning under $20 \mathrm{a} r$, där studenternas möjligheter till progression i utbildningen sägs vara "ett absolut krav som inte kan kompenseras eller balanseras mot andra behov eller krav. Om en utbildning inte tillfredsställer detta krav så ska den överhuvudtaget inte finnas som utbildning $\mathrm{i}$ högskolan" (SOU 20I5:70, s I9). Ett skäl till detta kan vara det ökande inflytandet av ENQA:s standarder, som bland annat innefattar att "[programmes] are designed so that they enable smooth student progression" (ESG, 20I5), vilket i UKÄ:s översättning blir "[Utbildningarna] är utformade så att de möjliggör en tydlig progression för studenterna” (UKÄ, 20I5, s I2).

\section{Progression och lärande}

I sin klassiska betydelse är progression en synonym till utveckling och framåtskridande (Svenska Akademien, 20I7), och tillskrivs den eller det som utvecklas ("sjukdomens progression", (Svenska Akademin, 20I7)) eller lär sig ("möjliggör... progression för studenterna" (UKÄ, 20I5, s I2)). Man kan se progression, eller utveckling, hos någon, vilket betyder att progression kan ses som en manifestation av lärande. Medan lärandet är den process som leder till ökad kunskap eller färdighet, är progressionen det sätt som lärandet tar sig till uttryck, det vill säga ett bevis för resultatet av lärandet. Någon tydlig definition av progression som individuell utveckling och hur det relateras till lärande verkar inte finnas. När progression används som en egenskap hos en kurs 
eller en utbildning är det dock inte utveckling av kursen eller utbildningen som åsyftas. Att "kurser byggs i en viss progression mot ett examensarbete" (UKÄ 20I4:II, s 23), betyder inte att byggandet sker genom kursutveckling, utan snarare att det ska synas att kurserna utgör byggstenar i en process som leder till ett examensarbete. Någon tydlig definition av progression som kvalitet i en kurs eller utbildning, och dess relation till individuell progression, verkar inte finnas. Ordet progression kan således avse dels utveckling i sig, och dels en kvalitet hos utbildning eller undervisning.

Elmgren \& Henriksson (2013) kopplar progressionsbegreppet till olika taxonomier, däribland Blooms taxonomi och SOLO-taxonomin. Taxonomierna utgör modeller för att ordna olika former av kunskap, från enkla former till komplexa, men de kan inte utgöra några universella progressionsmodeller då de förutsätter ett visst perspektiv på lärande. När lärandeprocesser studeras empiriskt visar de sig ofta vara icke-linjära (Pirie \& Kieran, 1994; Sikorski \& Hammer, 20ıO; Thom \& Pirie, 2006); individen cirkulerar mellan mer primitiva och mer avancerade idéer, mellan att upptäcka detaljer och att se strukturer (Thom \& Pirie, 2006). SOLO-taxonomin ordnar kunskap från unistrukturell till multistrukturell, relationell och utvidgat abstrakt, där identifiering och beskrivning anses vara enklare förmågor än jämförelser och kontrastering (Elmgren \& Henriksson, 2013, s I59). Biggs (1996) relaterar denna taxonomi till konstruktivism och fenomenografi, två perspektiv där konflikter, kontraster och relationer mellan idéer är grundläggande processer i lärande. I variationsteorin, sprungen ur fenomenografin, ses rent av kontraster och jämförelser som förutsättningar för att något ska kunna identifieras och beskrivas (Marton \& Tsui, 2004). Den hierarkiska ordningen i Blooms taxonomi, där vetande och förståelse anses enklare än tillämpning och reflektion, saknar empiriskt stöd (Marzano \& Kendall, 2007, s 8), och motsägs av studier som visar att studenter lättare lär sig begrepp om de först får förbereda sig genom aktiviteter där begreppen kan tillämpas (Schwartz \& Bransford, 1998). Med andra ord kan man bara lära sig begrepp om man "ställs inför en uppgift som inte kan lösas på annat sätt än att genom att bilda begrepp" (Vygotskij, 1934/I999, s I73), vilket betyder att tillämpning måste föregå förståelse. Blooms taxonomi är också oförenlig med pragmatiska teorier om lärande, där handling ses som en förutsättning för kunskap (Molander, I996, s 9). Kunskap och förståelse är då snarare något som uppstår genom samspelet mellan handling, erfarenheter och reflektion (Schön, 1983; Dewey, 1903, 1910, 1938).

I en anglosaxisk kontext kan man skilja på progress och progression, där progress kan ses som ett mer vardagligt begrepp i betydelsen utveckling eller framåtrörelse (Oxford University Press, 20I7). Flera myndigheter och organisationer använder learning progressions i policydokument kring skolutveckling (Corcoran, Mosher \& Rogat, 2009; Heritage, 2008; Ministry of Education, 20IO), och det har genomförts en mängd studier kring detta (se t.ex. Sikorski \& Hammer (2010)), men det finns inte någon koncensus kring begreppets betydelse (Heritage, 2008, s 4; Land \& Drake, 20I4, s IIo). Den grundläggande idén är dock att det går att formulera en hierarkisk standardstruktur av kunskapsblock (färdigheter, sätt att tänka, insikter), som beskriver hur elever och studenter lär sig ett ämne över tid. Strukturen beskriver studenternas förväntade progression, vilket bör ligga som grund för de didaktiska val som görs under utbildningen. Inom Bolognasystemet kan de så kallade Dublindeskriptorerna ses som ett exempel på detta (European Higher Education Area, u.å.). Den kritik som förs fram mot användandet av learning progressions liknar till viss del kritiken mot Blooms taxonomi, så till vida att den ifrågasätter huruvida kunskap verkligen kan ordnas på detta hierarkiska sätt. Empiriska studier visar att studenters 
kunskap inte kan beskrivas av koherenta, kvalitativt skilda nivåer, eftersom kunskap är kontextberoende (Sikorski \& Hammer, 2oro, s 6). Även om learning progressions är menade som en modell snarare än en regel, finns risken att de blir styrande, och därmed att läraren inte tar hänsyn till studenternas förkunskaper och resonemang (Sikorski \& Hammer, 20IO, s 5).

\section{Syfte och frägeställning}

Progression har blivit en allt viktigare aspekt av kvalitet i högre utbildning i Sverige, trots att progression som egenskap hos utbildning inte är ett väldefinierat begrepp. Medan till exempel vetenskaplighet som begrepp har problematiserats grundligt under lång tid, verkar begreppet progression ha undgått närmre granskning. Syftet med denna studie är att undersöka innebörden och användningen av ordet progression inom högre utbildning genom att besvara frågan: I vilka betydelser används ordet progression inom svensk högre utbildning, och hur har användningen forrändrats över tid?

\section{METOD}

Med syftet att undersöka innebörden och användningen av ordet progression inom högre utbildning genomfördes en systematisk begreppsanalys (Nuopponen 20IOa, 20IOb, 20II) av ordet progression. Metoden har utvecklats för att kunna användas i forskning inom olika fält, och kombinerar element från terminologisk begreppsanalys med begreppsanalys som används inom företagsekonomi och vårdvetenskap (Nuopponen, 20IOa, s 5). Nuopponen (20IOb) beskriver metoden som uppdelad i sex steg (Fig I), varav de två första utgörs av avgränsning och generell förståelse för fältet, vilket presenterades i bakgrunden. Följande tre steg utgör databearbetning och analys, vilket beskrivs nedan. Resultatet av det femte steget utgör denna studies resultat. Det sjätte steget ledde fram till den slutsats som presenteras i studiens sista avsnitt.

\section{Sammansättning av datamaterial}

Då fokus i denna studie ligger på hur det svenska ordet används inom högre utbildning i Sverige, avgränsades datamaterialet till tre textsamlingar: vetenskapliga texter på svenska (Swepubmaterialet), offentligt tryck från regering, riksdag, HSV och UKÄ (det statliga materialet), samt texter sökbara på svenska lärosätens hemsidor (lärosätesmaterialet). Valet av textsamlingar syftar till att täcka in användningen av ordet progression i såväl forskningssammanhang, som statlig styrning och lärosätenas dagliga verksamhet.

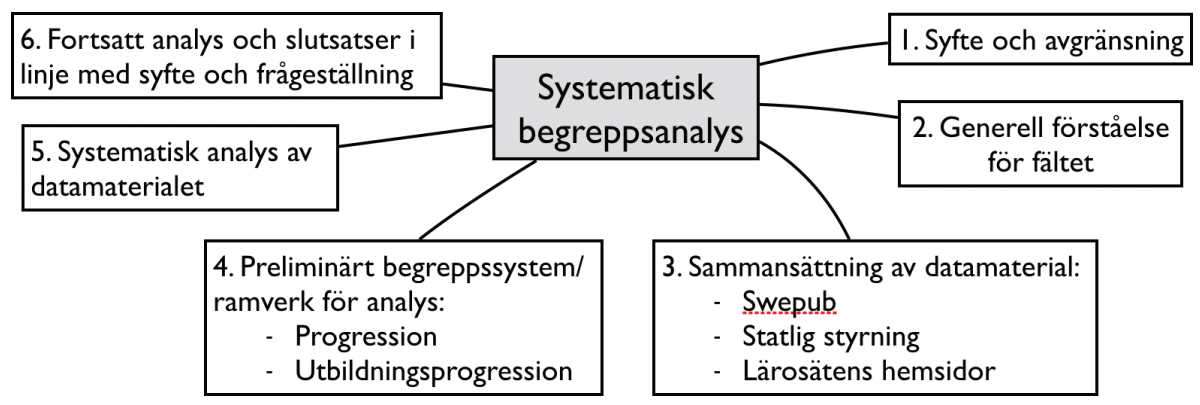

Fig I. De sex stegen i systematisk begreppsanalys, anpassad för studie av progression i högre utbildning, utifrån Nuopponen (2010b). 
De vetenskapliga texterna samlades in genom sökningar i databasen Swepub. Dessa sökningar gjordes för att ta reda på hur begreppen används av svenska forskare i granskade och publicerade texter. Sökningen gjordes i november 20I5, och avgränsades till träffar på svenska. Totalt hittades I28 källor. Av dessa tillhörde 24 det medicinska området och använde begreppet i relation till sjukdomsförlopp och dylikt, varför dessa valdes bort. Av de återstående föll ytterligare is källor bort, främst konferensbidrag, då de var omöjliga att finna eller använde ordet utan sammanhang. Kvar återstod 89 källor publicerade under perioden 1997-20I5, fördelade på avhandlingar (30 st), konferensbidrag (22 st), tidskriftsartiklar (I4 st), rapporter (I3 st), böcker och bokkapitel (8 st), samt en forskningsöversikt och ett samlingsverk. Dessa texter utgör Swepubmaterialet.

Sökningarna hos UKÄ gjordes för att ta reda på hur begreppen använts i dokument för statlig styrning, och genomfördes runt årsskiftet 20I5/I6. Det första fallet där progression användes var 2004. Materialet kompletterades med andra viktiga texter för styrning av högre utbildning under perioden 1998-20I5, för att ge en bild av det statliga språkbruket även tiden före begreppet progression infördes. Bland dessa texter hittades en tidigare förkomst av ordet progression i en proposition. Av de totalt 28 texterna är I2 rapporter av HSV eller UKÄ, 6 beslut av HSV eller UKÄ, 4 propositioner, 2 lagändringar, 2 rapporter från utbildningsdepartementet, I statlig offentlig utredning och I promemoria. Dessa källor utgör det statliga materialet.

Som ett komplement till de källor som hittades i Swepub och via UKÄ samlades texter från svenska lärosäten in. Dessa texter var tänkta att ge en bild av hur begreppen används i de dokument som universitetslärare använder i sin dagliga verksamhet. Då sökningar på enbart "progression" ledde till en ohanterlig mängd irrelevanta träffar, bland annat för att vissa lärosäten använder begreppet för att karaktärisera kurser, begränsades sökningarna genom att använda söksträngen "vetenskaplig progression". Denna begränsning valdes därför att den vetenskapliga grunden är ett krav på allı högre utbildning (SFS I992:I434, I kap. 2\$), medan progression inom till exempel praktiska moment enbart rör vissa utbildningar. Någon sådan inskränkning gjordes dock inte nästa fas, då hela texterna analyserades, även om de också behandlade annan progression än vetenskaplig. Sökningarna gjordes i december 20I5. Tabell I visar vilka lärosätens hemsidor som användes för sökningar, och vilka som gav träffar i sökningarna. Av de fjorton lärosätenas texter ${ }^{2}$ utgörs två av presentationsbilder, nio av beskrivningar av studenters förväntade progression (learning progressions), och tre av längre utredande texter om progression som utmynnar i learning progressions. Dessa källor utgör lärosätesmaterialet.

\section{Preliminärt begreppssystem och systematisk analys}

Ordet progression står för minst två olika begrepp, vilket vi såg i bakgrunden. Framförallt går en skiljelinje mellan progression som utveckling eller manifestation av lärande, något studenter kan uppvisa, och progression som egenskap hos utbildningar, program och kurser. Det preliminära begreppssystemet består av dessa två begrepp:

Progression (P): progression som synonym till utveckling (t.ex. hos en person), eller som manifestation av lärande. Detta är ordets klassiska betydelse.

1 Frånsett konstnärlig utbildning.

2 Linköpings universitet genererade tre texter, övriga lärosäten en text vardera. För enkelhetens skull behandlas även texterna från Linköpings universitet som en helhet. Alla tre texterna berör lärarutbildningen och kan ses som delar i ett arbete om progression. 
Tabell I. Sammanfattning av de lärosäten där sökningar gjordes. Lärosäten vars hemsidor genererade träffar är markerade med grått. Tabellen ska inte förstås som en förteckning över vilka

lärosäten som arbetar med vetenskaplig progression i sina utbildningar, utan endast som en förteckning över de lärosäten där dokument om vetenskaplig progression gick att finna genom sökning på lärosätets hemsida i december 2015 .

\begin{tabular}{lll}
\hline Blekinge tekniska högskola & Högskolan i Skövde & Lunds universitet \\
Chalmers tekniska högskola & Högskolan Kristianstad & Malmö högskola \\
Gymnastik och idrottshögskolan & Högskolan Väst & Mittuniversitetet \\
Göteborgs universitet & Karlstads universitet & Mälardalens högskola \\
Högskolan Dalarna & Karolinska institutet & Stockholms universitet \\
Högskolan i Borås & Kungliga Tekniska högskolan & Södertörns högskola \\
Högskolan i Gävle & Linköpings universitet & Umeå universitet \\
Högskolan i Halmstad & Linnéuniversitetet & Uppsala universitet \\
Högskolan i Jönköping & Luleå tekniska universitet & Örebro universitet \\
\hline
\end{tabular}

Utbildningsprogression (UP): en kvalitet hos en utbildning, del av utbildning eller i undervisning, mål eller läromedel.

I samtliga källor söktes efter ordet progression, och alla förekomster markerades. Därefter klassificerades förekomsterna efter hur begreppet progression användes: som manifestation av lärande eller synonym till utveckling hos studenten, eller som en kvalitet i undervisning eller utbildning. För de fall då det var svårt att avgöra vad som avsågs med begreppet, eller när det användes i båda betydelserna skapades en särskild kategori som fick namnet "otydlig/inkonsekvent". Klassifikationen användes både som data för redovisning av kvantitativa resultat kring hur begreppets betydelse förändrats över tid, och som underlag för en djupare, kvalitativ analys av vilken innebörd olika författare tillskriver ordet progression. Analysen fokuserade på hur de två betydelserna av begreppet relateras till varandra och till andra begrepp inom utbildningsvetenskap. Särskilt noterades problematiseringar av begreppet, sammansättningar av ordet, och vilka formuleringar som användes. Under analysen av texterna hämtade från lärosätenas hemsidor noterades också ifall texterna kopplade progression till någon taxonomi eller annan teoretisk beskrivning av kunskapsformer och -nivåer, samt om texterna innefattade någon form av beskrivning av studenters förväntade progression, det vill säga learning progressions (Heritage, 2008).

\section{Metoddiskussion}

Då såväl Swepub, som UKÄs och lärosätenas hemsidor ständigt uppdateras kan datamaterialet inte anses vara fullständigt. Det bör särskilt nämnas att äldre dokument från myndigheter som lagts ner ibland har varit svåra att finna. Vidare ger resultatet en bild av hur ordet progression använts under de senaste decennierna fram till december 20I5, då sökningarna gjordes. Detta betyder att det kan ha tillkommit beskrivningar och problematiseringar av progression i högre utbildning under det senaste året, som denna studie inte har fångat upp. Under den tidsperiod källorna täcker, kan de olika textsamlingarna dock ses komplettera varandra: Swepubmaterialet består av vetenskapliga texter och kurslitteratur, och bör därför ge en bild av i vilken utsträckning progression är väldefinierat och problematiserat som begrepp. Texterna från lärosätenas hemsidor kompletterar denna bild, och speglar också hur ordet progression används i lärosätenas 
dagliga verksamhet. Slutligen visar det statliga materialet hur UKÄ, Utbildningsdepartementet och regeringen använder ordet progression, vilket gör det möjligt att undersöka hur de påverkat språkbruket inom den svenska högskolesektorn.

Samtliga texter som analyserats hämtades i elektronisk form, och i första fasen av analysen gjordes sökningar i de elektroniska texterna med hjälp av webbläsare eller pdf-läsare. Detta medförde att risken för att några förekomster av ordet progression missats är liten, och att materialet gjordes mer hanterbart, då endast avsnitt med förekomster av ordet analyserades. Avgränsningen kan teoretiskt sett ha påverkat förståelsen och tolkningen av författarnas avsikter, men risken bedöms som liten då relativt långa utsnitt kring ordet gjordes, vilka utökades om betydelsen var oklar.

\section{RESULTAT}

Den första delen av detta avsnitt beskriver olika innebörd och användning av ordet progression i allmänhet, och vetenskaplig progression i synnerhet. Den andra delen beskriver hur ordets innebörd och användning har förändrats över tid.

\section{Användning och betydelse}

I de flesta fall används ordet progression som en synonym till utveckling. I Swepubmaterialet används progression i flera fall i relation till textanalys (t.ex. tematisk progression, narrative progression) och utveckling av till exempel projekt utan koppling till utbildning och lärande. I det övriga materialet används oftast ordet progression som något studenter kan genomgå eller uppvisa. Lärosätena skriver att studenterna förväntas genomgå en progression under utbildningen, som leder fram till vissa kunskaper och färdigheter, eller en yrkesroll (Hesslefors, Carle \& Engberg, 20IO; Karlstads universitet, u.å; Klinth \& Lindgren, u.å; Lång, 20I2). De talar om att följa studenters progression (Mälardalens högskola, 20I2), eller att studenterna ska få syn på sin egen progression (Hesslefors, Carle \& Engberg, 2010), och beskriver denna progression som fördjupning och breddning (Hultin, u.å). Denna typ av formuleringar står också att finna i flera av de statliga dokumenten där det ofta talas om den progression som sker inom, eller i, utbildning (Ds 2004:2; HSV 2008:8R; Prop. 2004/05:162; Prop. 2009/10:89), men också explicit om studenters progression (HSV, 20I2; Prop. 2009/Io:89). Särskilt vanligt är formuleringar om att utbildningen eller undervisningen säkrar, garanterar eller försvårar (studenters) progression (HSV 2007:59R; HSV 2008:8R; HSV, 20II; Prop. 2004/05:I62; UKÄ, 2013, 20I4a, 20I4c, 20I5b).

I vissa fall är det svårt att avgöra vad som avses: studenters progression eller utbildningsprogression. En vanlig formulering i såväl det statliga, som Swepub- och lärosätesmaterialet är progression mellan och inom moment eller kurser (Ds 2004:2; Högskolan i Halmstad, u.å; Klinth \& Lindgren, u.å; Linköpings universitet, 2010; Linnéuniversitetet, 2012; Prop 2009/I0:89), vilket kan syfta på både studentens utveckling och kursernas utformning. Man talar också ofta om ämnets progression och progression i kursplaner och andra målformuleringar (Hesslefors, Carle \& Engberg, 20IO; HSV 2007:3IR; Högskolan i Skövde, 20II; Liwång, 2005). Lärare har ansvar för att skapa progression i undervisning och lärande, genomföra en tanke om progression, och ge uttryck för vikten av en väl genomtänkt progression (Aulin \& Jönsson, 2009; Hesslefors, Carle \& Engberg, 20IO; HSV 2006:46R; Jonsson, 2006; Stenberg \& Meckbach, 20I2, november).

Att lyfta fram progression i utbildningen som en viktig kvalitetsaspekt visar sig vara en relativt ny företeelse. I 1998 och 200 års utgångspunkter för de nationella utvärderingarna 
(HSV 1998:2IR; HSV 200I:2R), nämns inte progression alls, men i slutrapporten för granskningarna 200I-2006 (HSV 2007:3IR) är det ett framträdande tema. Här används begreppet progression som en egenskap hos utbildningen; man talar om att utbildningar visar på dålig progression mellan olika utbildningsmoment och om progressionen i teori- och metodundervisningen (HSV 2007:3IR). Även i två kronologiskt närliggande rapporter nämns progression i undervisningen (HSV 2006:46R) och utbildningens progression (HSV 2007:59R). I rapporten HSV2008:8R är progression något en utbildning kan ha och som kan tydliggöras, förbättras och ökas, eller vara svår att överblicka. Utifrån kursplaner kan det avgöras om progressionen är tillräcklig. Om utbildningen är tydlig och strukturerad, utan för stor valfrihet för studenten, bidrar det till en bättre progression. Liknande formuleringar återfinns i lärosätesmaterialet, medan texterna i Swepubmaterialet oftast utan närmare förklaring talar om utbildningens progression. Det sägs dock att kurser kan utgöra en progression (Karlsson \& Sonesson, 20I2) och att uppläggningen kan bilda en hårt strukturerad progression (Lundberg, 2007). Det första exemplet på utbildningsprogression i Swepubmaterialet handlar om progression i litteratur (Arklund, Bergner \& Östlund, 1998), vilket också återkommer hos Ammert (2008) och i HSV 2008:8R.

Under remissförfarandet inför införandet av Bolognasystemet framkom att "andra [lärosäten] anser att progressionsbegreppet bör förtydligas" (Prop. 2004/05:I62, s 96), men någon tydlig definition eller förklaring av vad som menas med progression i utbildning och undervisning går inte att finna hos UKÄ. Två av de längre lärosätestexterna visar också på en uttalad otydlighet kring hur begreppet ska tolkas, samtidigt som det förs fram som avgörande för hur utbildningen ska utformas. I ett fall påstås det att "tanken om progression förutsätter vissa idéer om hur lärande- och utvecklingsprocesser går till” (Klinth \& Lindgren, u.å, s 8). Även om det ingenstans i materialet finns en tydlig definition av det som här kallas utbildningsprogression, kan aspekter av vad som avses utläsas i flera fall, särskilt i Swepubmaterialet. Organisation och ordning av undervisningsmoment så att de bygger på varandra relateras till progression (Orlenius, 2004; Lindeborg, 2006), medan avsaknad av progression beskrivs som att lektionerna hoppar från den ena aktiviteten till den andra (Lundberg, 2007). Denna slags progression kopplas också till lärande, då man menar att utbildningens progression ska stödja studentens process (Gustavsson, 2008). Utbildningsdepartementet går till och med så långt att de påstår att "nivåindelningen av examina och kurser, samt målbeskrivningar för examina på olika nivåer, tydligt visar att en progression sker i utbildningen som helhet" (Ds 2004:2, s 89).

De tre längre texterna från lärosäten knyter alla idén om progression till olika taxonomier och beskrivningar av kunskapsformer och utveckling. Alla tre relaterar till SOLO-taxonomin (Hesslefors, Carle \& Engberg, 2oıo; Klinth \& Lindberg, u.å; Lång, 20I2), medan endast två tar upp Blooms taxonomi (Hesslefors, Carle \& Engberg, 20I0; Klinth \& Lindberg, u.å). Det förekommer också andra modeller för nivåer av kunskap, såsom Millers pyramid (Klinth \& Lindberg, u.å; Lång, 20I2) och Dublindeskriptorerna (Hesslefors, Carle \& Engberg, 20IO; Klinth \& Lindberg, u.å). En text lyfter fram Bruners spiral som ett alternativ till de linjära modellerna av progression (Klinth \& Lindberg, u.å).

\section{Förekomst och utveckling över tid}

Den kvantitativa sammanställningen visar att användningen av progression i båda betydelserna har ökat drastiskt de två senaste decennierna, både vid lärosätena och hos myndigheterna. 
Sökningen i Swepub efter svenska texter innehållande ordet "progression" visar en tydlig ökning av texter från mitten av oo-talet, och det talas allt oftare om progression i utbildning och undervisning.

Figur 2 visar de valda källorna i Swepub för sökordet "progression" med avgränsning språk: svenska, för olika användning av begreppet progression. Svart symboliserar träffar där begreppet progression enbart används som en synonym till lärande eller utveckling, och vitt sådana träffar där progression används enbart som en kvalitet i undervisning eller utbildning. Grått symboliserar de träffar där betydelsen är tvetydig eller där begreppet används i båda betydelserna. Den första texten som talar om progression som en kvalitet hos utbildning är publicerad 2004.

Bland de statliga texterna om skola och utbildning nämner många inte progression alls (Tabell 2). Första gången begreppet förekommer är i en proposition 2000, då det på ett ställe förs fram att "många poängmässigt små inslag i lärarutbildningen försvårar progression i ett ämne" (Prop. 1999/2000:I35). Nästa förekomst är Utbildningsdepartementets rapport Högre utbildning i utveckling - Bolognaprocessen i svensk belysning (Ds 2004:2), där man flera gånger talar om progression i utbildningen. Vi ser även i det statliga materialet en förskjutning i användningen av ordet progression mot betydelsen utbildningsprogression. Det är särskilt intressant att utbildningsprogression förekommer i slutrapporter och beslut om examenstillstånd, och därmed visar sig vara en viktig kvalitetsaspekt, utan att det först förekommit i beskrivningar av kvalitetssäkringssystemet. Den proposition som ligger till grund för HSVs och senare UKÄs granskningar 2OII2014 nämner inte progression (Prop. 2009/IO:I39), och det gör heller inte HSV:s riktlinjer (HSV 20II:4R; HSV 20I2:I5R). När det gäller den nya lärarutbildningen talas främst om progression "i studierna" och "för studenten" (Prop. 2009/ro:89).

I figur 3 visas hur ordet progression används i lärosätenas texter. Då det totala antalet texter var litet (I4 st), och då alla texter hämtades vid samma tillfälle, och det inte alltid framgick när texten var skriven, redovisas inte utveckling över tid. Det framgår dock att progression även i dessa texter används med olika och ibland otydliga betydelser.

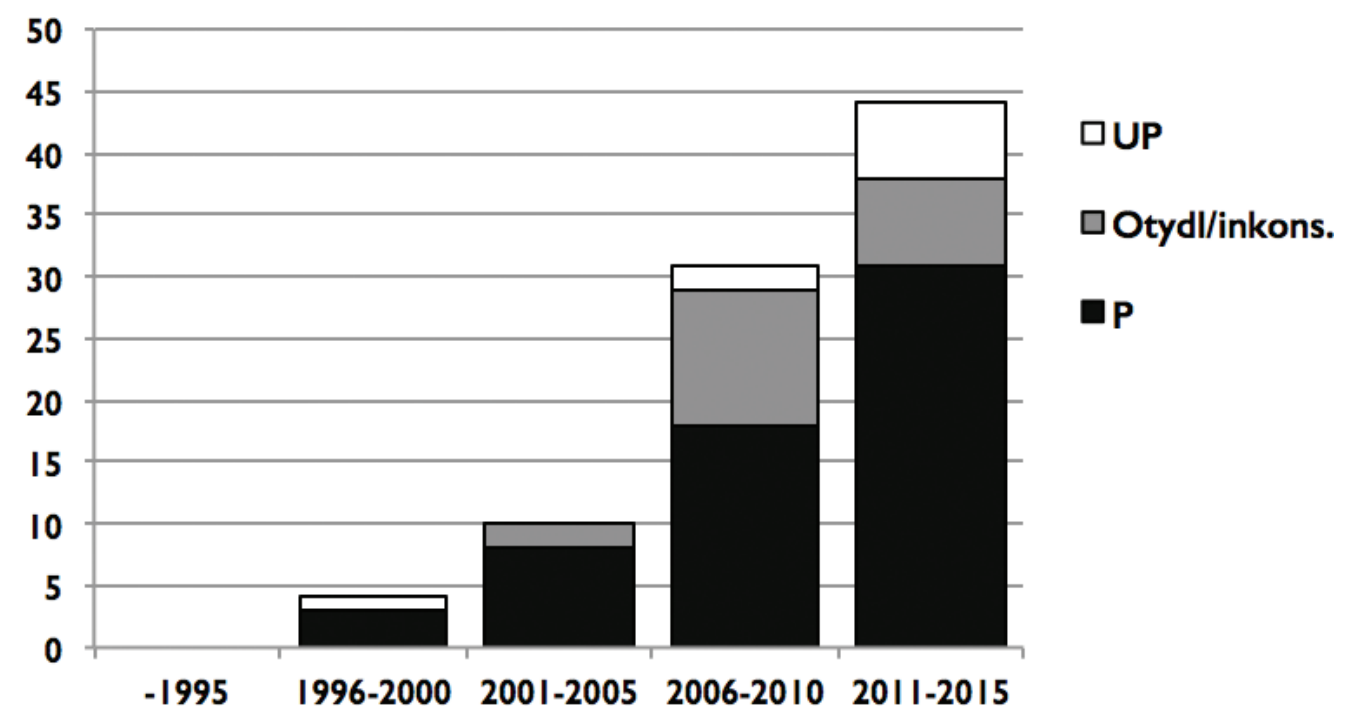

Fig 2. Olika sätt att använda ordet progression i texter i Swepub under olika femårsintervall. 
Högre utbildning 65

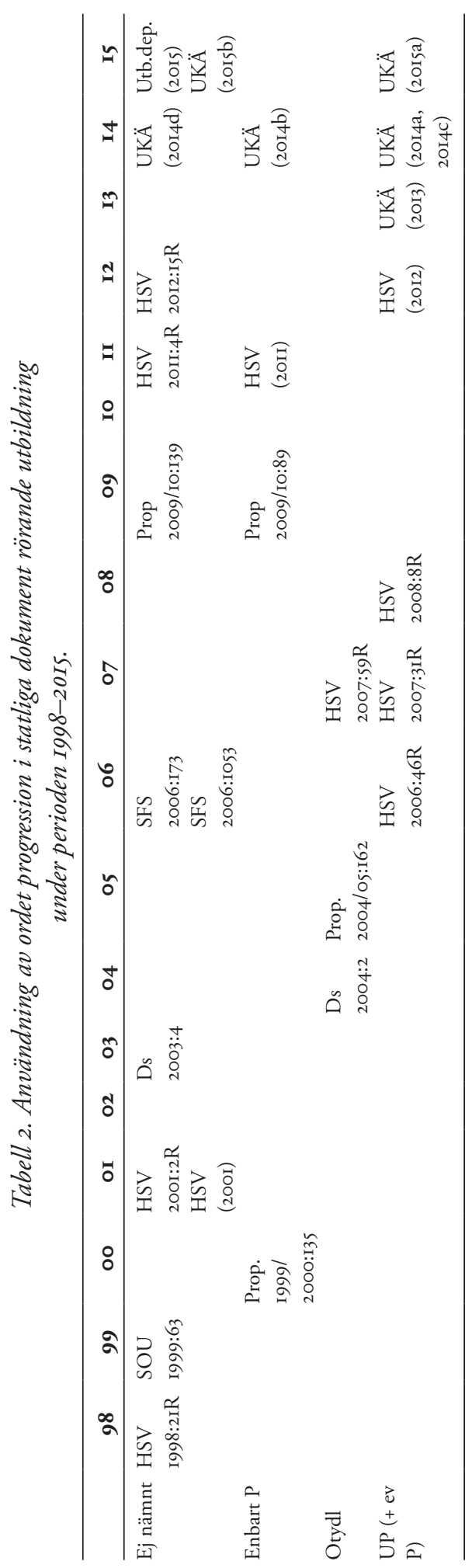




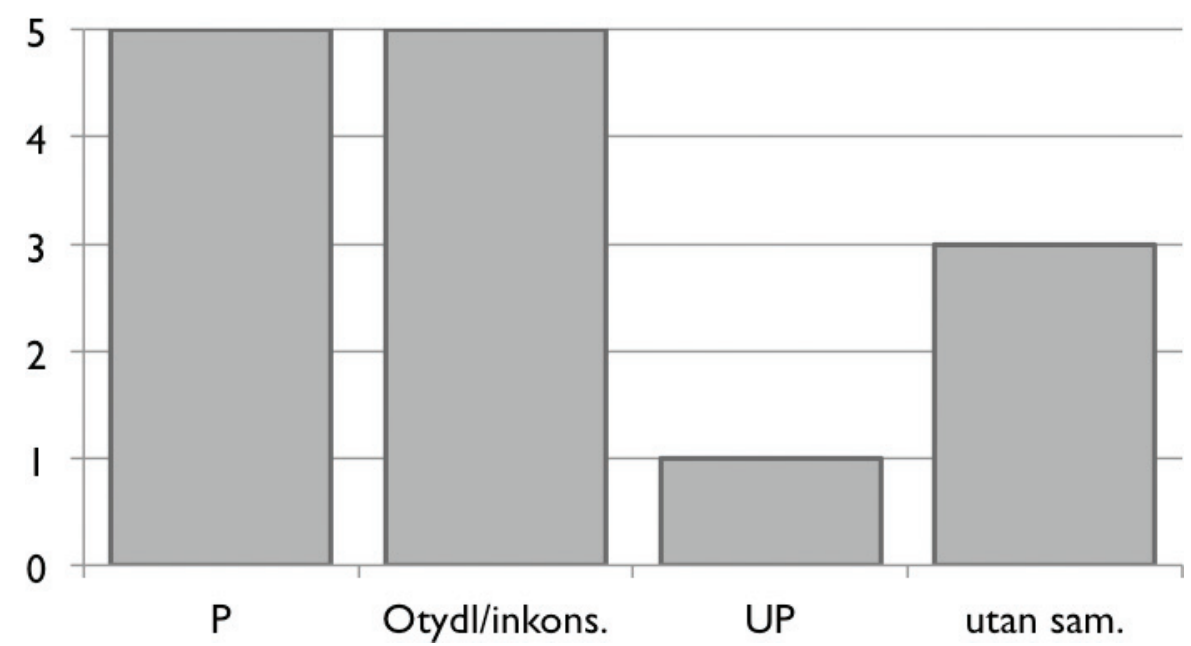

Fig 3. Olika sätt att använda ordet progression i lärosätenas texter.

\section{SLUTSATS OCH DISKUSSION}

Analysen visar att användningen av ordet progression har ökat sedan mitten på oo-talet, både i dokument för statlig styrning och i forskares och lärares egen textproduktion. Ökningen stämmer i tid med Bolognaprocessen och införandet av en ny utbildningsstruktur (UKÄ, 20I7). Det blir också tydligt att det har skett en förskjutning i användningen av ordet progression, såväl i statliga rapporter som i vetenskapliga texter. Efter att ursprungligen ha beskrivit en utveckling hos enskilda studenter över tid, har begreppet alltmer använts som en kvalitet i utbildning och undervisning. Denna glidning i betydelse har dock inte uppmärksammats i texterna, och det saknas förklaringar av vad progression i utbildning och undervisning egentligen betyder. Denna förskjutning kan inte direkt härledas från riktlinjerna för Bolognaprocessen, då de endast skriver om studenters progression (ESG, 2015). I och med autonomireformen har dock kvalitetssäkring av utbildning blivit en allt viktigare fråga (Buhre, 20I4), och därmed har behovet att tala om kvaliteter i utbildning ökat. Progression som kvalitet i utbildning verkar fylla en viktig funktion.

Den klassiska betydelsen av progression fångar dock endast det ena begreppet kopplat till ordet - det som ligger nära begreppen lärande och utveckling. För att fånga det andra begreppet, då kvaliteteter i utbildning, undervisning eller läromedel avses, föreslås att benämningen utbildningsprogression införs, och ges följande definition:

Med utbildningsprogression menas att det (i en utbildning, en serie lektioner eller ett läromedel) ställs successivt ökande krav, som är möjliga att uppnå med hjälp av tidigare förväntat lärande.

Definitionen definierar den form av progression som fördes fram i datamaterialet, nämligen att progression som kvalitet $\mathrm{i}$ utbildning innebär att ordna undervisningen i moment som bygger på varandra. Formuleringen speglar viljan att avgränsa sig dels mot fall då kraven ligger på en konstant nivå, vilket kan betyda meningslös repetition, dels mot fall då kraven ökas så mycket att de inte kan mötas av studenten. Begreppet är tänkt att spegla den dubbla ambitionen att 
samtidigt som möjligheter för lärande och utveckling skapas, reducera möjligheterna att genomgå en utbildning utan att lära sig och utvecklas. Liknande tankar förs fram av Elmgren och Henriksson (2013, s I40), som menar att "en tydlig progression genom utbildningen bygger på att kunskaper och färdigheter från tidigare kurser tas till vara". Det är viktigt att särskilja de två begreppen, då organisation av utbildning och undervisning, till exempel i form av nivåindelning av kurser och målbeskrivningar för examina på olika nivåer (Ds 2004:2), kan vara en förutsättning för, men aldrig garantera att progression sker hos enskilda studenter. Att studera och granska progressionen i utbildningens utformning är aldrig liktydigt med att granska progressionen hos studenterna.

I en av lärosätestexterna påstods att tanken om progression förutsätter vissa idéer om hur lärande- och utvecklingsprocesser går till. Detta är dock endast sant om man kopplar samman progression med taxonomier, vilka i många fall motsäger etablerade lärandeteorier (t.ex. Dewey, 1938; Marton \& Tsui, 2004; Molander, 1996; Schön, 1983; Vygotskij, 1934/1999) och empiriska resultat (t.ex. Schwartz \& Bransford, I998; Sikorski \& Hammer, 20I0; Thom \& Pirie, 2006). Med den definition av utbildningsprogression som föreslås ovan, kan progression förstås på olika sätt inom olika perspektiv på lärande och kunskap. Ändå diskuterar många av lärosätena progression utifrån just taxonomier, och de statliga dokumenten kan sägas implicera en oproblematisk relation mellan utbildningsprogression och studenters progression och lärande. Det finns en risk att denna syn på progression blir normerande och påverkar lärosätenas utformning av utbildning och undervisning, precis som kunskapssynen i UKÄs utvärderingar (Buhre, 20I4).

Flera av lärosätena har också utformat matriser med lärandemål på olika nivåer. Matriserna utgör en beskrivning av förväntad utveckling i studentens kunskap och färdigheter; de är alltså en slags learning progressions; men är ofta tänkta att användas som bedömningsunderlag. Detta kan vara problematiskt, då utbildningsvetenskaplig forskning visar att lärande sällan är en linjär process (Pirie \& Kieran, 1994; Sikorski \& Hammer, 2010; Thom \& Pirie, 2006). Om learning progressions, som från början var tänkta som en beskrivning av den förväntade lärprocessen hos en "standardelev", används för bedömning anses den styrande effekten inte bara vara en risk (Sikorski \& Hammer, 2010), utan en realitet.

Det måste dock inte vara så. Genom att klargöra och problematisera begrepp kan högskolor och universitet själva påverka sättet att tänka på undervisning, och inte enbart, som Clegg (2009) skriver, formas av det språkbruk som införs av andra aktörer. Betydelsen av ökande krav och tidigare lärande beror på hur lärande och kunskap definieras, och vilket sorts kunskap som utbildningen syftar till. Relationen mellan undervisning, eller organisering av utbildning i vidare bemärkelse, och lärande är inte självklar, vilket den omfattande forskningen inom utbildningsvetenskap visar. Just eftersom metoder och tekniker som har visats underlätta lärande inte kan räknas som garantier, är det problematiskt att använda begreppet progression både för manifestationer av lärande och för en kvalitet i utbildning. En oreflekterad användning av begreppen kan leda till antaganden om att ökande krav per se leder till lärande och att, som vissa av de statliga texterna menar, utformningen av kurser och målbeskrivningarna $i$ sig visar på att studenterna genomgår progression. I den högre utbildningen kan man förvisso hävda att lärarens ansvar i första hand är att tillhandahålla högkvalitativ utbildning, medan ansvaret för lärandet i hög grad ligger på studenten, men det är dock viktigt att understryka att detta inte är det samma som att hävda att högkvalitativ utbildning är liktydigt med den enskilda studentens lärande. Då UKÄ framför progression i utbildningen som ett absolut krav för en utbildnings 
existensberättigande (SOU 20I5:70), är det av högsta vikt för högskolesektorn att veta om det är studenters progression eller utbildningsprogression som avses. Att analysera innebörden och användningen av begrepp är således inte bara en viktig del av vetenskaplig forskning (Nuopponen, 20II), utan också viktigt när det gäller begrepp relaterade till utformning av högre utbildning.

Det kan tyckas lätt att se en koppling mellan å ena sidan progression i utbildning och undervisning, och å andra sidan progression i kunskaper hos studenten. Vi kan se det som självklart att undervisning som utgår från studentens nuvarande kunskaper och utmanar studenten genom ökade krav, ger goda förutsättningar för lärande. Vi vet dock också att sådan undervisning inte garanterar lärande hos enskilda studenter, eftersom det finns många andra faktorer som spelar in, och därför att ansvaret för lärande ytterst ligger hos studenten. Det finns också bekvämlighetsskäl att fokusera på utbildningen, då den är dokumenterad i standardformat i offentliga dokument, medan det är svårare att få syn på och analysera studenternas lärande. Det kan därför verka rimligt och rättvist att utvärdera utbildningens och undervisningens progression, snarare än studenternas.

En möjlig förklaring till den ökade användningen av begreppet progression är att författare vill komma bort från det komplexa och teoriladdade begreppet lärande. Eftersom progression hänger så intimt ihop med lärande blir detta dock en falsk neutralitet, och som vi sett kan vissa tolkningar av begreppet stå i strid med de lärandeteorier som vi utgår ifrån i andra delar av utbildningen. Till exempel utgörs ofta den lägsta nivån i lärosätenas progressionsdokument av att veta eller kunna redogöra för något, medan att praktiskt kunna utföra något utgör en högre nivå, vilket kan härledas från taxonomier som Blooms taxonomi, Millers pyramid och Dublindeskriptorerna. Teorier och forskning inom lärande skriver dock ofta fram vikten av egen erfarenhet och handlande som utgångspunkt för den reflektion som leder till kunskap (Dewey, I938/20I5; Marton \& Tsui, 2004; Molander, 1996; Schwartz \& Bransford, I998; Schön, 1983). Även om teoretisering av kunskap är en viktig del av vetenskap, kan praktisk kunskap gå förlorad $i$ en sådan process, och även inom forskning är en stor del av kunskapen praktisk (Molander, 1996). Man kan således ifrågasätta vilken kunskap man uppvisar om man kan redogöra för hur något görs innan man själv kan göra det.

Progression måste förstås i relation till ett lärandeperspektiv, och olika perspektiv leder till mycket olika tolkningar av vad progression innebär. Det återstår att avgöra om utbildningsprogression, så som det definieras ovan, faktiskt leder till ökat lärande och bättre resultat. Definitionen i sig implicerar inte detta. Det är först i dialog med en lärandeteori som utbildningsprogression kan preciseras och motiveras, och som utsagor om dess förtjänster kan testas empiriskt.

\section{FÖRFATTARPRESENTATION}

Författaren är lektor i matematikdidaktik vid Högskolan i Halmstad och bedriver forskning inom utbildningsvetenskap och matematikdidaktik. Hon undervisar och handleder i matematik, matematikdidaktik och utbildningsvetenskap inom lärarutbildningarna med inriktning mot undervisning i grundskolan och gymnasiet. I rollen som studierektor leder hon arbetet med måluppfyllelse och kvalitet i grundlärarutbildningarna vid lärosätet.

\section{KÄLLMATERIAL}

Texter insamlade via Swepub

Alpenberg, J. (2005). Investeringar i mindre och medelstora tillverkande företag: Drivkrafter, struktur, process och beslut. (Doktorsavhandling, Lunds Universitet, Lund, Lund Studies in Economics and Management 82). 
Alvehus, J. (2006). Paragrafer och profit: Om kunskapsarbetets oklarhet. (Doktorsavhandling, Lunds Universitet, Lund).

Ammert, N. (2008). Det osamtidigas samtidighet: historiemedvetande $i$ svenska historieläroböcker under hundra år. (Doktorsavhandling, Lunds universitet, Lund).

Andersson Chronholm, J., Larsson, J., \& Andersson, G. (2013, april). Förstaårsstudenters och lärares syn på laborationer $i$ fysik. Konferensbidrag presenterat på Teknisk-naturvetenskapliga fakultetens universitetspedagogiska konferens, Uppsala, Sverige.

Andersson Chronholm, J., Larsson, J., \& Andersson, G. (20I4, oktober). Förstaårsstudenters och lärares förhållningssätt till laborationer i fysik. Konferensbidrag presenterat på NU2OI4, Umeå, Sverige.

Andersson, P-Y. (2004). Överskridandets strategier: lyrisk romankonst och dess uttryck hos Rosendahl, Trotzig och Lillpers. (Doktorsavhandling, Örebro Universitet, Örebro, Örebro Studies in Literary History and Criticism).

Andræ, M. (200I). Rött eller grönt? Flicka blir kvinna och pojke blir man i B. Wahlströms ungdomsböcker 19I4-1944. (Doktorsavhandling, Uppsala Universitet, Uppsala, Skrifter utgivna av Svenska barnboksinstitutet 73).

Arklund, G., Bergner, E., \& Östberg, U. (1998). Fokus på Sverige. Lund: Studentlitteratur.

Aulin, R., \& Jönsson, K. (2009). Att inspirera till akademisk hederlighet i högre utbildning: Lärarens roll. I A. Sonesson \& G Amnér (Reds.), Utvecklingskonferens, Lunds universitet 09: Konferensbidrag frän Utvecklingskonferens (s. 138). Lund: Lunds universitet.

Bengtsson, A. (20IO). Nykterhetsorganisationer, politik och historieberättande: Strikt manliga angelägenheter? I L. Berggren, K.-G. Karlsson \& C. Tornbjer (Red.), Möten med historiens mångfald (s. 217-229). Lund: Nordic Academic Press.

Berndsson, I. (20II). Lärande inom rehabilitering för personer med synnedsättning. I Förbundet Sveriges arbetsterapeuter, AT-forum abstrakt: Konferensbidrag från AT-forum (s 25). Nacka: Förbundet för Sveriges arbetsterapeuter.

Boström, U. (20I4). "När man kollar på bilden tänker man så här": En receptionsstudie av gymnasieelevers uppfattning om bilder som kunskapskällor i historieundervisningen. (Licentiatavhandling, Umeå universitet, Umeå, Licentiatavhandlingar från forskarskolan Historiska medier 8).

Buhre, F. (20I4). Universitetskanslerämbetets kunskapssyn: En granskning av en granskning. Högre Utbildning 4(I), 5-17.

Byqvist, S. (1997). Svenska narkotikamissbrukande kvinnor och män: missbruksfölopp och kriminalitet. (Doktorsavhandling, Stockholms Universitet, Stockholm).

Bäckström, A. (2006). Kyrkan och utbildningarna. Svensk kyrkotidning, 43, 543-545.

Bäckström, A., \& Haikola, L. (2007a). Prövning av ansökan frän Johannelunds teologiska högskola om rätt att utfärda magisterexamen $i$ teologi. Stockholm: Högskoleverket.

Bäckström, A., \& Haikola, L. (2007b). Prövning av ansökan från Teologiska högskolan i Stockholm om rätt att utfärda magisterexamen samt masterexamen i teologi. Stockholm: Högskoleverket.

Bäckström, A., \& Haikola, L. (2007c). Prövning av ansökan frän Örebro teologiska högskola om rätt att utfärda magisterexamen i teologi. Stockholm: Högskoleverket.

Cronholm, S., Lind, M., \& Hjalmarsson, A. (20IO). Samverkan kring kompetensförsörjning: Temporär arbetskraft som strategisk framgångsfaktor. Borås: Högskolan i Borås.

Dimenäs, J. (2007). Undervisningens röda tråd: Möjligheter i naturvetenskap. Lund: Studentlitteratur.

Dimenäs, J., Johansson, K., Karlsson, L., \& Svensson, L. (20II, december). Några preliminära resultat av en utvärdering av Försvarshögskolans verksamhetsförlagda utbildning. Konferensbidrag presenterat på VILÄR 20II, Skövde, Sverige.

Dolatkhah, M. (20II). Det läsande barnet: minnen av läspraktiker, 1900-1940. (Doktorsavhandling, Högskolan i Borås, Borås, Skrifter från Valfrid 48).

Eckert, G., Alm, C., Estling, F., Jakobsson, E., \& Tyrberg, M. (2006). Du kan väl spela psykolog: Att få en känsla av kontinuitet och progression. Ett nytt sätt att undervisa i samtals-och testmetod på ett psykologprogram. Konferensbidrag presenterat på Utvecklingskonferensen 2005, Lund, Sverige. 


\section{A.I. Säfström}

Edberg, A.-K., Ehrenberg, A., Friberg, F., Wallin, L., Wijk, H., \& Öhlén, J. (Red.). (2013). Omvårdnad på avancerad nivå: Kärnkompetenser inom sjuksköterskans specialistområden. Lund: Studentlitteratur.

Ehrlin, A., \& Gustavsson, H.-O. (20I4, april). Musik ska spela roll förskolan: men rustar förskollärarutbildningen för uppdraget. Konferensbidrag presenterat på Nordiskt nätverk för musikpedagogisk forskning, Stockholm, Sverige.

Einarson, D. (2013). Progressioner inom en projekt-baserad kurs baserad på principer från Software Engineering och CDIO. I S. Larsson (Red.), Lärarlärdom: Konferensbidrag frän Högskolepedagogisk konferens (s. 6-25). Kristianstad: Kristianstad University Press.

Engblom, C. (2012). Yngre barns skärmbaserade texthantering: Multimodala texter och nya perspektiv på progression och bedömning. I J. Magnusson, A. Malmbjer \& D. Wojahn (Reds.), Språket, kroppen och rummet: Multimodala och digitala perspektiv på lärande: Konferensbidrag frän den Åttonde nationella konferensen i svenska med didaktisk inriktning (s. 35-50). Stockholm: SMDI.

Ericson, M. (20II). Nära inpå: Maskulinitet, intimitet och gemenskap $i$ brandmäns arbetslag. (Doktorsavhandling, Göteborgs Universitet, Göteborg).

Eriksson, G. (2005). Tidig aritmetisk kunskapsbildning: Ett radikalkonstruktivistiskt perspektiv. (Doktorsavhandling, Stockholms universitet, Stockholm, Studies in Educational Sciences 76).

Ernstsson, U. (2006). Kontrakt med naturen: Om spridning och implementering av miljöledningssystem. (Doktorsavhandling, Göteborgs Universitet, Göteborg, Meddelanden från Göteborgs Universitets geografiska institutioner Serie B 109).

Fischer, O. (1998). Tecknets tragedi: symbol och allegori i Atterboms sagospel Lycksalighetens ö. (Doktorsavhandling, Uppsala Universitet, Uppsala).

Flyman Mattsson, A., Rosén, C., Simfors, P., \& Sundberg, A.-K. (2013). Språklig progression i läromedel för $S f$ (ASLA:s skriftserie 24). Linköping: Linköpings universitet.

Fransson, J., \& Ohlsson, M. (20I4). Forskares och studenters användning av LUBsearch: En studie i användning av och användbarhet hos ett discoverysystem. Lund: Lunds universitet.

Färnlöf, H. (20IO). Intratextuell motivering: Berättande och berättigande i ett urval fransk I80o-talsprosa. I S. Packalén (Red.), Theodor Kallifatides, Bodil Malmsten, Hugo Hamilton, fransk I8oo-talsprosa, Marcel Pagnol, Vilhelm Moberg, språkundervisning (Litteratur och språk 6). Västerås: Mälardalens högskola.

Galt, S. (20I2, januari). Systematisk feedback och progression som stöd för studenters lärande inom generella kompetenser. Konferensbidrag presenterat på KUL 20I2: Chalmers Konferens om Undervisning och Lärande, Göteborg, Sverige.

Gullström, C. (2013). Arkitekturskolans självvärderingsrapport till Universitetskanslerämbetet. Stockholm: KTH.

Gustavsson, S. (2008). Motståndochmening: Innebördiblivandeläraresseminariesamtal. (Doktorsavhandling, Göteborgs Universitet, Göteborg, Göteborg Studies in Educational Sciences 266).

Gårdfeldt, G., Khoso, M., \& Karlsson, K. A. (2010). Lucia möter Pajazzo: Kvinnorollen och mansrollen $i$ opera då och nu. Redovisning av ett konstnärligt utvecklingsprojekt. Göteborg: Göteborgs Universitet.

Hackman, B. (2000). Jag kan sjunga hur jag vill: tankevärld och konstsyn i Edith Södergrans diktning. (Doktorsavhandling, Uppsala Universitet, Uppsala, Acta Universitatis Upsaliensis 340).

Hanse, E., Wahlqvist, M., Sturm, A., Lindholm, C., Haraldsson, B., Andersson, R., \& Manhem, K. (20II). Läkarprogrammet i Göteborg moderniserar: Professionell utveckling, forskningsanknytning och internationalisering i fokus. Läkartidningen, I2(I08), 669-673.

Hansson, Ö. (2003). En studie i lärarstuderandes begreppsuppfattning: "Vi skriver $\mathrm{y}=\mathrm{x}+5$. Vad betyder det?". Tsunami, $I$.

Höstmad, P., Ingelhammar, C., \& Suneson, K. (2015, november). Ämnesstråks, lärsekvens-, och profilansvariga som stöd i programutveckling. Konferensbidrag presenterat på s:e utvecklingskonferensen för Sveriges ingenjörsutbildningar, Uppsala, Sverige.

Ingvar, M., \& Boström, A.-K. (20I4). En bättre skolstart för alla: Bedömning och betyg för progression $i$ lärandet. Stockholm: Utbildningsdepartementet. 
Johansson, A.-M. (20I2). Undersökande arbetssätt i NO-undervisningen i grundskolans tidigare årskurser. (Doktorsavhandling, Stockholms universitet, Stockholm, Studies in science and technology education 58, Doctoral thesis from the department of mathematics and science education 7).

Jonsson, C. (2006). Läsningens och skrivandets bilder: En analys av villkor och möjligheter för barns läs- och skrivutveckling. (Doktorsavhandling, Umeå Universitet, Umeå, Doktorsavhandlingar inom den Nationella Forskarskolan i Pedagogiskt Arbete 2, Doktorsavhandlingar i pedagogiskt arbete 10).

Jönsson, M. (20I5). Behovet av närhet blir med àren betydligt större än nödvändigheten att bevara sin värdighet: Om genus, trots och åldrande i Kerstin Thorvalls författarskap. Lund: Ellerströms förlag.

Karlsson, L. \& Sonesson, A. (2OI2). Kompetensutveckling för forskarhandledare: Rapport från ett samverkansprojekt mellan Läranderesurscentrum vid Högskolan Kristianstad och Centre for Educational Development (CED) vid Lunds Universitet. I Högskolepedagogisk debatt handledning, internationalisering (s. 67-77). Kristianstad: Högskolan Kristianstad.

Kellner, E., \& Attorps, I. (20I4). Kollegialt lärande om progression i biologi- och matematikundervisning. Nämnaren, 4I(4), 3-8.

Krantz, J. (2009). Styrning och mening: Anspråk på professionellt handlande i lärarutbildning och skola. (Doktorsavhandling, Växjö universitet, Växjö, Acta Wexionensia I8I).

Kvist, R. (20II). Äktenskap och social status hos Dalregementets underofficerare I72I-I809. Konferensbidrag presenterat på Historikermötet, Göteborg, Sverige.

Käck, A., \& Oldsjö, F. (2OI2). Kursplanearbete och kursutveckling. I A. Käck \& S. Männikkö-Barbutiu, Digital kompetens i lärarutbildningen: Ett integrationsperspektiv (s. 8I-94). Lund: Studentlitteratur.

Landqvist, H., Cromdal, J., Persson Thunqvist, D., \& Osvaldsson, K. (2012). Om man frågar får man svar: Två öppningsrutiner för SOS-ärenden och deras konsekvenser för samtalens inledning. Språk \& stil, $22(2), 127-152$.

Lindberg, Y., \& Sandblom, E. (20I4, november). Svenskämnets tre inneboende svårigheter. Konferensbidrag presenterat på Vetenskapsrådets resultatdialog, Jönköping, Sverige.

Lindberg, Y., \& Sandholm, E. (2015, maj). Att utveckla skrivkompetens på gymnasiet. Konferensbidrag presenterat på Skriv! Les! - Nordisk forskerkonferanse om lesing, skriving og literacy, Stavanger, Norge.

Lindeborg, R. (2006). Örats skolning: Radiokonservatoriet och musikbildningsarbetet. (Doktorsavhandling, Stockholms universitet, Stockholm, Skrifter från Centrum för musikpedagogisk forskning 7).

Lindgren, C., \& Klinth, R. (2009). Progression i en Bolognaanpassad lärarutbildning (Rapportserie, I4). Linköping: Centrum för undervisning och lärande.

Lindquist, G. (1997). Små barns lek: Vuxnas gestaltning och barns meningsskapande. Karlstad: Högskolan i Karlstad.

Lindström, U., Johansson, E., Bodlund, O., \& Hamberg, K. (2008). Professionell utveckling: Så förs ämnet stegvis in i läkarutbildningen i Umeå. Läkartidningen, I05(I2-I3), 909-913.

Liwång, H. (2005). Officersutbildningen svår teknisk balansgång. Framsyn, I, 36-38.

Lundberg, G. (2007). Teachers in Action: Att förändra och utveckla undervisning och lärande i engelska $i$ de tidigare skolåren. (Licentiatavhandling, Umeå universitet, Umeå, Licentiatavhandlingar vid Pedagogiska institutionen 4).

Lundegård, I. (2007). På väg mot pluralism: Elever $i$ situerade samtal kring hållbar utveckling. (Doktorsavhandling, Stockholms Universitet, Stockholm, Studies in educational sciences IOI).

Medina, E. (2013). Från "tyst vår" till "hållbar utveckling": En kritisk diskursanalys av miljöfrågans utveckling 1962-1987. (Doktorsavhandling, Uppsala universitet, Uppsala).

Mejtoft, S., \& Berglund, S. (20I4, oktober). Projektledning som miljö för ökade generiska färdigheter. Konferensbidrag presenterat på NU2OI4, Umeå, Sverige.

Mortensen, A. (2000). Tradition och originalitet hos Gunnar Ekelöf. (Doktorsavhandling, Lunds Universitet, Lund).

Norberg Brorsson, B. (2007). Man liksom bara skriver: Skrivande och skrivkontexter i grundskolans år 7 och 8. (Doktorsavhandling, Mälardalens högskola och Örebro Universitet, Örebro, Studier från Örebro i svenska språket 2). 
Nygren, T., \& Åstrand, B. (2012). En splittrad historia: Sambandet mellan kursplaner i historia för gymnasieskola och högre utbildning. Norddidactica-Journal of Humanities and Social Science Education, 2, I-30.

Nylén, A. (20I2, oktober). Progression i skrivfärdigheter hos studenter i datavetenskap. Konferensbidrag presenterat på NU2OI2, Göteborg, Sverige.

Orlenius, K. (2004). Progression i lärarutbildningen. Tidskrift för lärarutbildning och forskning, 3-4, II7-I30.

Packalén, S. (Red.). (20IO). Theodor Kallifatides, Bodil Malmsten, Hugo Hamilton, fransk I8oo-talsprosa, Marcel Pagnol, Vilhelm Moberg, språkundervisning (Litteratur och språk 6). Västerås: Mälardalens högskola.

Pelger, S., \& Santesson, S. (2014, december). Kommunikationsträning i civilingenjörsprogrammen. Konferensbidrag presenterat på 8:e pedagogiska inspirationskonferensen, Lund, Sverige.

Persson, H. (2013, april). Kunskapsutveckling $i$ historia. Konferensbidrag presenterat vid Kritiska perspektiv på historiedidaktiken: Sjunde årliga konferensen inom nationella nätverket för historiedidaktisk forskning, Linköping, Sverige.

Roback, K., \& Carlsson, P. (2009). Evidensgraderingssystemet GRADE: Ett sätt att granska vetenskaplig kunskap om metoder och arbetssätt $i$ hälso- och sjukvården (CMT-rapport 2009:3). Linköping: Linköping University Electronic Press.

Rosén, C. (2009). Textproduktion i andraspråksundervisning: Varför låter en svensk "svensk" oh en tysk "tysk"? I Språk och lärande: Rapport från ASLA:s höstsymposium (s. 173-188). Stockholm: Stockholms Universitet.

Rosén, C., \& Bohnacker, U. (2009). Fundamentet i svenskan och tyskan: Syntax och informationsstruktur. Språk \& Stil, I9, I42-I7I.

Rosengren, C. (2013). Mål, progression och resultat i humanistiska händer. I T. Forser \& T. Karlsohn (Red.), Till vilken nytta? En bok om humanioras möligheter (s. I5I-158). Göteborg: Daidalos.

Schiöler, K. (20I2). Kurskonstruktörer i ett målstyrt system. (Licentiatavhandling, Karlstads universitet, Karlstad, Karlstad University Studies 20I2:I2, Studier i de samhällsvetenskapliga ämnenas didaktik I8).

Simon, J. (2009). Kreativitetens kännetecken: En fenomenologisk studie. (Doktorsavhandling, Stockholms Universitet, Stockholm, Doktorsavhandlingar från Pedagogiska institutionen 158).

Simonsson, K., Renner, J., Hallberg, P., \& Simonsson, M. (20I4). Kamratutvärdering $i$ kurser med stort datorlaborativt inslag. Linköping: Linköping University Electronic Press.

Stenberg, K. \& Meckbach, J. (20I2, november). Den reflekterande friluftsläraren. Konferensbidrag presenterat på SVEBIs årskonferens, Umeå, Sverige.

Stenberg, K., \& Meckbach, J. (20I2). Den reflekterande friluftsläraren. Idrottsforum.org. Hämtad från http://idrottsforum.org/stenberg-meckbachı20919/

Sundström, M. (2013). Vad kan vi vänta oss av 20I4? Hämtad från Retailingresearch.blogspot.com

Törnquist, E-M. (2006). Att iscensätta lärande: Lärares reflektioner över det pedagogiska arbetet $i$ en konstnärlig kontext. (Doktorsavhandling, Malmö Högskola och Lunds Universitet, Studies in music and music education).

Wallsten, L. (20II). Anteckningar om Spår: Fotografi - Bevis - Bild. (Doktorsavhandling, Göteborgs Universitet, Göteborg, ArtMonitor - Avhandlingsserien 24).

Warnby, M. \& Sundblad, B. (2006, april). Tröskelvärden och kvalitativ progression i lärarutbildningen. Konferensbidrag presenterat på den sjunde nationella kvalitetskonferensen, Lärarhögskolan, Stockholm, Sverige.

Wendel, M. (20IO, augusti). Fri tankeprocess och medvetenhet om kreativitet: En studie av studenters kreativa utveckling i kursen Kreativitet, idéer och innovation ur ett psykologiskt perspektiv. Konferensbidrag presenterat på Lärarlärdom: Högskolepedagogisk konferens, Karlskrona, Sverige.

Wenglén, R. (2005). Från dum till klok? En studie av mellanchefers lärande.(Doktorsavhandling, Lunds universitet, Lund).

Westermark, C. (20I4). Implementering av redovisning som styrmetod: Om hållbarhetsredovisningens effekter i statligt ägda företag. (Doktorsavhandling, Stockholms universitet, Stockholm). 
Wikberg-Nilsson, Å., \& Gedda, O. (2012). Pedagogisk idé LTU: uttryck och riktlinjer för implementering. Luleå: Luleå tekniska universitet.

Öhman, G. (20I2). Idé och innovation. (Licentiatavhandling, Mittuniversitetet, Sundsvall, Mid Sweden University licentiate thesis 85 ).

\section{Dokument för statlig styrning}

Ds 2003:4. Magisterexamen i nationell belysning. Stockholm: Utbildningsdepartementet.

Ds 2004:2. Högre utbildning $i$ utveckling - Bolognaprocessen $i$ svensk belysning. Stockholm: Utbildningsdepartementet.

HSV 1998:2IR. Fortsatt granskning och bedömning av kvalitetsarbetet vid universitet och högskolor: Utgångspunkter samt angrepps- och tillvägagångssätt för Högskoleverkets bedömningsarbete. Stockholm: Högskoleverket.

HSV 200I:2R. Nationella ämnes- och programutvärderingar. Stockholm: Högskoleverket.

HSV 2006:46R. Utbildning på vetenskaplig grund - röster från fältet. Stockholm: Högskoleverket.

HSV 2007:3I R. Hur har det gått? En slutrapport om Högskoleverkets kvalitetsgranskningar åren 200I-2006.

HSV 2007:59R. Nationellt kvalitetssäkringssystem för perioden 2007-2012. Reviderad 2007-I2-II. Stockholm: Högskoleverket.

HSV 2008:8R. Uppföljande utvärdering av lärarutbildningen. Stockholm: Högskoleverket.

HSV 20I:4R. Generell vägledning för självvärdering $i$ Högskoleverkets system för kvalitetsutvärdering. Stockholm: Högskoleverket.

HSV 20I2:I5R. Högskoleverkets system för kvalitetsutvärdering 20II-20I4: Examina på grundnivå och avancerad nivå. Stockholm: Högskoleverket.

HSV. (200I). Ribban på rätt nivå: sju inlägg om högskolemässighet. Stockholm: Högskoleverket.

HSV. (20II). Vägledning inför prövning av examenstillstånd för lärarexamina. Stockholm: Högskoleverket.

HSV. (2012). Uppföljning av granskning av kurser som inte specifikt omfattas av kursfordringarna för någon examen (Reg.nr 643-02945-I2). Stockholm: Högskoleverket.

Prop. 1999/2000:135. En förnyad lärarutbildning.

Prop. 2004/05:I62. Ny värld - ny högskola.

Prop. 2009/10:89. Bäst $i$ klassen - ny lärarutbildning.

Prop. 2009/IO:139. Fokus på kunskap - kvalitet i den högre utbildningen.

SFS 2006:173. Lag om ändring i högskolelagen.

SFS 2006:1053. Förordning om ändring $i$ högskoleförordningen.

SOU 1999:63. Att lära och leda: en lärarutbildning för samverkan och utveckling: Lärarutbildningskommitténs slutbetänkande. Stockholm: Utbildningsdepartementet.

UKÄ. (2OI3). Beslut om tillstånd att utfärda grundlärarexamen med inriktning mot arbete i förskoleklass och grundskolans årskurs I-3 (Reg.nr 42-59-13). Stockholm: Universitetskanslersämbetet.

UKÄ. (20I4a). Karlstads universitets ansökan om tillstånd att utfärda psykologexamen (Reg.nr 42-96-I4). Stockholm: Universitetskanslersämbetet.

UKÄ. (20I4b). Kvalitetsaspekter vid examenstillständsprövning av generella examina. Stockholm: Universitetskanslersämbetet.

UKÄ. (20I4c). Lunds universitet ansökan om tillstånd att utfärda ämneslärarexamen med inriktning mot arbetet $i$ gymnasieskolan (Reg.nr 42-664-I3, 42-666-I3, 42-668-13, 42-670-I3, 42-672-I3, 42-673-I3, 42-675-13). Stockholm: Universitetskanslersämbetet.

UKÄ. (20I4d). Universitetskanslersämbetets prövning av ansökan om tillstånd att utfärda masterexamen. Stockholm: Universitetskanslersämbetet.

UKÄ. (2015a). Högskolan Dalarnas ansökan om tillstånd att utfärda ämneslärarexamen med inriktning mot arbete $i$ gymnasieskolan $i$ undervisningsämnet matematik (Reg.nr 42-432-I4). Stockholm: Universitetskanslersämbetet.

UKÄ. (20I5b). Standarder och riktlinjer för kvalitetssäkring inom det europeiska området för högre utbildning (ESG). Stockholm: Universitetskanslersämbetet. 


\section{A.I. Säfström}

Utbildningsdepartementet. (2015). Kvalitetssäkring av högre utbildning (Promemoria U2015/1626/UH). Stockholm: Utbildningsdepartementet.

Texter hämtade på lärosätens hemsidor

Gustavsson, M., \& Gustafsson, C. (u.å). Vetenskapligheten i lärarutbildningen. Hämtad 3 december 2015 från www.hig.se

Gymnastik- och idrottshögskolan (20II). Utbildningsplan: Tränarprogrammet, I20/I80 högskolepoüng. Hämtad 3 december 2015 från www.gih.se

Hesslefors, E., Carle, J., \& Engberg, H. (2010). Bolognaperspektiv: Om progressionslinjer inom Lärarprogrammet vid Göteborgs universitet. Hämtad 3 december 2015 från www.gu.se

Hultin, E. (u.å). Progression inför examensarbetet i nya lärarutbildningen. Hämtad 3 december 2015 från www.du.se Högskolan i Borås. (u.å). [Progressionsmatris]. Hämtad 3 december 2015 från www.hb.se

Högskolan i Halmstad (u.å). Progressionsdokument för examinatorer, övningar och vetenskaplig nivå. Hämtad 3 december 2015 från www.hh.se

Högskolan i Skövde. (20II). Ämnet omvårdnad - definition, beskrivning och progression. Hämtad 3 december 2015 från www.his.se

Karlstads universitet. (u.å). Lärarprogrammet vid Karlstads universitet. Hämtad 3 december 2015 från www. kau.se

Klinth, R., \& Lindgren, C. (u.å). Progression vid Lärarprogrammet i Norrköping och Lärarprogrammet i Linköping. Hämtad 3 december 2015 från www.liu.se

Linköpings universitet. (2010). Progression och integration i ny lärarutbildning. Hämtad 3 december 2015 från www.liu.se

Linköpings universitet. (u.å). Progression i didaktiskt- och vetenskapligt kunnande samt internationalisering - vetenskaplig produktion. Hämtad 3 december 2015 från www.liu.se

Linnéuniversitetet. (20I2). Vetenskaplig progression i lärarutbildningar vid Linnéuniversitetet. Hämtad 3 december 2015 från www.lnu.se

Lång, P. (20I2). Progressionstrappa i vetenskapligt förhållningssätt och forskningsmetodik för biomedicinska analytiker programmet. Hämtad 3 december 2015 från www.ki.se

Mälardalens högskola. (20I2). Sammanställning av diskussioner om forskningsbas. Hämtad 3 december 2015 från www.mdh.se

Stockholms universitet. (u.å). [Progressionsmatris]. Hämtad 3 december 2015 från www.su.se

Södertörns högskola. (u.å). [Progressionsmatris]. Hämtad 3 december 2015 från www.sh.se

\section{REFERENSER}

Adamson, L. (maj 2013). Kvalitetsutvärdering av högre utbildning - en kritisk granskning av det svenska systemet. Studieförbundet Näringsliv och Samhälles (SNS) Utbildningskommission. Hämtad från http://www.sns.se/sites/default/files/kvalitetsutvardering_av_hogre_utbildning.pdf

Biggs, J. (1996). Enhancing teaching through constructive alignment. Higher Education, 32, 347-364.

Buhre, F. (20I4). En granskning av en granskning: Universitetskanslersämbetets kunskapssyn. Högre utbildning, 4(I), 5-I7.

Clegg, S. (2009). Forms of knowing and academic development practice. Studies in Higher Education, $34(4), 403-416$.

Corcoran, T., Mosher, F.A., \& Rogat, A. (2009). Learning progressions in science: An Evidence-based approach to reform. Hämtad från http://www.cpre.org/images/stories/cpre_pdfs/lp_science_rr63.pdf

Dewey, J. (1903). Studies in logical theory. Chicago: The University of Chicago Press.

Dewey, J. (1910/2013). How we think. US: Important books.

Dewey, J. (1938/20I5). Experience and education. New York: Simon \& Schuster.

Elmgren, M. \& Henriksson, A-S. (2013). Universitetspedagogik (3. uppl.). Lund: Studentlitteratur.

ESG. (20I5). Standards and Guidelines for Quality Assurance in the European Higher Education Area. Brussels, Belgium. Hämtad från http://www.enqa.eu/wp-content/uploads/20I5/II/ESG_20I5.pdf 
European Higher Education Area. (u.å.) The framework of qualifications for the European Higher Education Area. Hämtad från http://ehea.info/

Heritage, M. (2008). Learning Progressions: Supporting Instruction and Formative Assessment. Washington, DC: Council of Chief State School Officers.

Land, T.J. \& Drake, C. (20I4). Enhancing and Enacting Curricular Progressions in Elementary Mathematics. Mathematical Thinking and Learning, I6, I09-134.

Marton, F. \& Tsui, A. (Red.) (2004). Classroom discourse and the space of learning. Mahwah, NJ: Lawrence Erlbaum.

Marzano, R.J. \& Kendall, J.S. (2007). The new taxonomy of educational objectives (2. ed.). Thousand Oaks, Calif: Corwin Press.

Ministry of Education, (2010). The Literacy Learning Progressions: Meating the reading and writing demands of the curriculum. Wellington, New Zealand: Learning Media Limited.

Molander, B. (1996). Kunskap i handling (2., omarb. uppl.). Göteborg: Daidalos.

Nuopponen, A. (20IOa). Methods of concept analysis - A comparative study. LSP Journal, I:I.

Nuopponen, A. (20Iob). Methods of concept analysis - Towards systematic concept analysis. LSP Journal, I:I.

Nuopponen, A. (20II). Methods of concept analysis - Tools for systematic concept analysis. LSP Journal, i:I.

Oxford University Press. (2017). Progress. Hämtad 2017-04-25 från https://en.oxforddictionaries.com/ definition/progress

Pirie, S. \& Kieran, T. (1994). Growth in mathematical understanding: How can we characterise it and how can we represent it? Educational Studies in Mathematics, 26, 165-190.

Prop. 1992/93:220. En ny läroplan för grundskolan och ett nytt betygsystem för grundskolan, sameskolan, specialskolan och den obligatoriska särskolan.

Prop. 1992/93:250. Ny läroplan och ett nytt betygssystem för gymnasieskolan, komvux, gymnasiesärskolan och särvux.

Prop. 2004/05:162. Ny värld - ny högskola.

Prop. 2009/10:89. Bäst $i$ klassen - ny lärarutbildning.

Prop. 2009/IO:I39. Fokus på kunskap - kvalitet $i$ den högre utbildningen.

Schwartz, D. L. \& Bransford, J. D. (1998). A time for telling. Cognition and instruction, 16(4), 475-522.

Schön, D. A. (1983). The reflective practitioner: How professionals think in action. New York: Basic books.

SFS I992:I434. Högskolelag.

SFS 2006:I73. Lag om ändring $i$ högskolelagen.

SFS 2006:I053. Förordning om ändring $i$ högskoleförordningen.

Sikorski, T. R., \& Hammer, D. (20I0). A critique of how learning progressions research conceptualizes sophistication and progress. In K. Gomez, L. Lyons, \& J. Radinsky (Eds.), ICLS'Io Proceedings of the gth international conferenceof the learning sciences (Vol. I, pp. I032-I039). Chicago, IL: International Society of the Learning Sciences.

SOU 2015:70. Högre utbildning under 20 år. Stockholm: Fritze.

Svenska Akademien. (2017). Svensk Ordbok (Version I.0.3). [Mobilapplikation]. Hämtad från http:// itunes.apple.com

Thom, J.S. \& Pirie, S. (2006). Looking at the complexity of two young children's understanding of number. The Journal of Mathematical Behavior, 25(3), I85-195.

UKÄ 20I4:II. Att utvärdera resultat $i$ högre utbildning: Reflektioner kring det svenska utvärderingssystemet. Stockholm: Universitetskanslersämbetet.

UKÄ. (20I5). Standarder och riktlinjer för kvalitetssäkring inom det europeiska området för högre utbildning (ESG). Stockholm: Universitetskanslersämbetet.

UKÄ. (20I7). Bolognaprocessen. Hämtad 2017-04-25 från http://www.uka.se/fakta-om-hogskolan/ bolognaprocessen.html

Vygotskij, L. S. (1934/1999). Tänkande och språk. Göteborg: Daidalos. 